\title{
A comparative analysis of self-treatment in a population of medical students in 2012 and 2017
}

\author{
ELŻBIETA KRAJEWSKA-KUŁAK ${ }^{1, A-F}$, AGNIESZKA KUŁAK-BEJDA ${ }^{2,8, ~ D-F}$, PIOTR KUŁAK ${ }^{3, \text { B, D-F, }}$ \\ GRZEGORZ BEJDA ${ }^{4, B, D-F}$, MATEUSZ CYBULSKI ${ }^{1, B, D-F}$, ANDRZEJ GUZOWSKI', B, D-F, \\ CECYLIA ŁUKASZUK ${ }^{1, B, ~ D-F}$, JOLANTA LEWKO ${ }^{1, B, ~ D-F}$, JOANNA FIŁON ${ }^{1, B, ~ D-F}$, \\ ANNA PILECKA ${ }^{6, E-F}$, WOJCIECH KUŁAK ${ }^{5, A-F}$ \\ ORCID ID: 0000-0003-1118-9139
}

${ }^{1}$ Department of Integrated Medical Care, Medical University of Bialystok

${ }^{2}$ Department of Psychiatry, Medical University of Bialystok

${ }^{3}$ Department of Pediatric Radiology, Medical University of Bialystok

${ }^{4}$ School of Medical Science in Bialystok

${ }^{5}$ Department of Pediatric Rehabilitation, Medical University of Bialystok

${ }^{6}$ PhD Student, Department of Integrated Medical Care, Medical University of Bialystok, Poland

A - Study Design, B - Data Collection, C - Statistical Analysis, D - Data Interpretation, E - Manuscript Preparation, F - Literature Search, G - Funds Collection

Summary Background. The use of over-the-counter (ОTC) medications without consulting a doctor has become increasingly common. Objectives. To compare the scale of self-treatment in a population of students of the Medical University of Bialystok in 2012 and 2017. Material and methods. The study included 217 students in 2012 and 220 students in 2017, and used a proprietary questionnaire. Results. A total of $78.8 \%$ of students in 2012 and $86.4 \%$ in 2017 were familiar with the meaning of the abbreviation OTC. When using an OTC drug for the first time, most students consulted a nurse (66.4\%) in 2012, while in 2017, students usually consulted a family member (68.8\%). Headache was the main reason for using OTC drugs (89.4\% in 2012, and $92.7 \%$ in 2017). The use of analgesics (87.1\%) and the use of OTC medicines in accordance with the leaflet (47\%) predominated in 2012, while vitamin therapy (83.2\%) took first place in 2017. When purchasing OTC medications, students usually based their decision on their own experience $(63.1 \%$ in 2012 and $84.1 \%$ in 2017). A total of $35.5 \%$ of the students in 2012 and $39.1 \%$ in 2017 always read the leaflet.

Conclusions. Self-medication was practiced by most students in both years, with lack of time for a medical appointment being the main reason. Over the last 6 months, the students most often used prescription and non-prescription drugs simultaneously. Key words: students, self medication, health.

Krajewska-Kułak E, Kułak-Bejda A, Kułak P, Bejda G, Cybulski M, Guzowski A, Łukaszuk C, Lewko J, Fiłon J, Pilecka A, Kułak W. A comparative analysis of self-treatment in a population of medical students in 2012 and 2017. Fam Med Prim Care Rev 2019; 21(1): 35-40, doi: https://doi.org/10.5114/fmpcr.2019.82977.

\section{Background}

The use of over-the-counter drugs (OTC) without prior consultation with a doctor is becoming increasingly common, all the more so that some of these drugs are available not only in pharmacies, but also at newsagents, supermarkets, herbal medicine shops, and even petrol stations. Their availability, low price, and the belief they are safe further increase the common use of OTC medications [1-4]. The World Health Organization (as cited in [5]) defines self-medication as "the use of medicines by individuals to treat self-diagnosed illnesses or symptoms". In practice, however, this term further includes mutual treatment among family members or friends, especially when the treatment is provided to a child (as cited in [5]). Self-treatment is an ambiguous term, which includes both self-medication and self-care [5].

Self-treatment is a relatively new phenomenon in Poland, as OTC medications were introduced on the pharmaceutical market at the beginning of the 1990s [6]. According to PMR Research on OTC products in Poland, pharmacy sales of OTC drugs in Poland will grow in value by about $6 \%$ on a yearly average between 2017 and 2022, with the market value of these products reaching PLN 19 billion in 2022 [7].

Medical students are those who will in the future provide patients with information on their health status and possible therapies, consult their pharmacotherapy by ordering discontinuation of inappropriate medications and prescribing effective ones, as well as decide on the course of their own treatment (which is often the case already during university).

\section{Objectives}

To compare the scale of self-treatment in a population of students of the Medical University of Bialystok in 2012 and 2017.

\section{Material and methods}

The study was approved by the Bioethics Committee of the Medical University of Bialystok (Approval No. R-I-002/2016/ 2011). The study included randomly selected students, including 217 students in 2012 and 220 students in 2017, aged 19-30 years old.

The study was conducted based on a diagnostic survey using a proprietary questionnaire composed of a sociodemographic part ( 7 questions) and the main part with 20 questions related to self-treatment: self-assessment of health status; compliance with doctor's recommendations; preferred behaviors when feeling ill, experiencing pain or any other symptoms; use of OTC 
drugs over the last 6 months; frequency of OTC drug use; consulting OTC drug use; situations in which they use these products; types of OTC drugs they use; familiarity with the OCT abbreviation; duration of self-treatment, reading leaflets for these medications; knowledge of adverse effects and the number of OTC medications used over the last 6 months.

We also used a questionnaire for the subjective assessment of family wealth (Perceived Family Wealth, PFW) $[8,9]$, which included one question: Do you consider your family to be wealthy? The respondents were asked to choose one of the following answers: very wealthy, rather wealthy, average, rather poor, or poor.

In the description of the results, self-medication was defined as the use of OTCs without consulting a doctor.

The chi-square test was employed in the statistical analysis. A value of $p<0.05$ was considered a statistically significant difference. Statistica 13.0 (StatSoft, Cracow, Poland) was used for analysis.

\section{Results}

The study included $3.7 \%$ men and $96.3 \%$ women in 2012 , and $10.9 \%$ men and $89.1 \%$ women in 2017 . A total of $27.2 \%$ of students in 2012 and $25.9 \%$ in 2017 were from rural settings, while $72.8 \%$ and $74.1 \%$ were from urban areas, respectively.

About $20.7 \%$ of all students in 2012 and $24.1 \%$ in 2017 assessed their health status as very good, $67.7 \%$ and $53.6 \%$ as good, respectively; $9.2 \%$ and $20.9 \%$ as not very good, respectively; and $2.4 \%$ and $1.4 \%$ as poor, respectively. A decrease in the rating of health status from "good" to "not very good" was observed in the analyzed period ( $p=0.005)$.

Regular compliance with doctors' recommendations was declared by $42.9 \%$ of the students in 2012 and $53.6 \%$ in 2017. An increasing tendency to declare "yes, I always comply with doctor's recommendations" compared with "yes, sometimes" was observed in the analyzed period; however, these correlations were not statistically significant.

When feeling ill, experiencing pain or other symptoms, the students in most cases did not visit their doctor, but used over-the-counter drugs or pharmaceuticals - 53.9\% in 2012 and $62.7 \%$ in 2017. An increasing trend in self-medication with OTC drugs or pharmaceuticals and a minor increase in the use of medications recommended by parents were observed among the students; however, these correlations were not statistically significant. All the other results are presented in Table 1.

\begin{tabular}{|c|c|c|c|}
\hline Students' behavior/action & 2012 & 2017 & $p$ \\
\hline $\begin{array}{l}\text { I do not visit my doctor, I use OTC } \\
\text { drugs or pharmaceuticals }\end{array}$ & $53.9 \%$ & $62.7 \%$ & NS \\
\hline $\begin{array}{l}\text { I limit myself to tested home rem- } \\
\text { edies }\end{array}$ & $22.1 \%$ & $21.8 \%$ & NS \\
\hline $\begin{array}{l}\text { I see my doctor immediately and use } \\
\text { the medications prescribed by him/her }\end{array}$ & $11.1 \%$ & $9.5 \%$ & NS \\
\hline $\begin{array}{l}\text { I do nothing, but try to wait until the } \\
\text { symptoms resolve }\end{array}$ & $5.1 \%$ & $3.2 \%$ & NS \\
\hline Depends on the symptoms & $3.2 \%$ & $0 \%$ & NS \\
\hline I use alternative medicine & $2.8 \%$ & $0.5 \%$ & 0.023 \\
\hline $\begin{array}{l}\text { I use medications recommended by } \\
\text { my parents }\end{array}$ & $1.8 \%$ & $2.3 \%$ & NS \\
\hline Total & $100 \%$ & $100 \%$ & \\
\hline
\end{tabular}

NS - non-significant.

The abbreviation OTC was interpreted correctly by $78.8 \%$ of the students in 2012 and $86.4 \%$ in 2017 ; whereas $6.4 \%$ and $2.2 \%$ of the students, respectively, had difficulties with providing an answer $(p=0.046)$. We found an increase in the number of respondents familiar with the OTC abbreviation and those who misinterpreted it.

The main reasons for self-treatment, in the opinion of students, were lack of time to visit a doctor $(66.8 \%$ in 2012 and $75.5 \%$ in 2017) or considering the symptoms to be too trivial and not requiring medical attention $(69.6 \%$ in 2012 and 55.5\% in 2017). A significant rise in the number of respondents $(p<0.001)$ convinced that self-medication works faster and is more effective was observed in the analyzed period $(11.1 \%$ in 2012 and 34.1\% in 2017). Results are shown in Table 2.

\begin{tabular}{|l|l|l|l|}
\hline \multicolumn{4}{|l|}{ Table 2. Students' opinions on reasons for self-treatment } \\
\hline Reasons* & 2012 & 2017 & $p$ \\
\hline $\begin{array}{l}\text { Symptoms are too trivial to } \\
\text { go to the doctor }\end{array}$ & $69.6 \%$ & $\mathbf{5 5 . 5 \%}$ & NS \\
\hline No time to visit the doctor & $\mathbf{6 6 . 8 \%}$ & $\mathbf{7 5 . 5 \%}$ & NS \\
\hline Difficult access to the doctor & $39.2 \%$ & $26.8 \%$ & NS \\
\hline $\begin{array}{l}\text { Self-medication is faster and } \\
\text { more effective }\end{array}$ & $11.1 \%$ & $34.1 \%$ & $<0.001$ \\
\hline $\begin{array}{l}\text { Lack of satisfaction with doc- } \\
\text { tor's advice }\end{array}$ & $9.2 \%$ & $8.2 \%$ & NS \\
\hline No money for the visit & $8.8 \%$ & $6.8 \%$ & NS \\
\hline $\begin{array}{l}\text { A belief that they can help } \\
\text { themselves better }\end{array}$ & $8.3 \%$ & $7.7 \%$ & NS \\
\hline $\begin{array}{l}\text { A belief that they know bet- } \\
\text { ter than their doctor }\end{array}$ & $2.3 \%$ & $5.5 \%$ & NS \\
\hline
\end{tabular}

* question with possibility of selecting multiple responses; NS - non-significant.

OTC medications were used by $47.9 \%$ of the students in 2012 and $61.7 \%$ in 2017 . Occasional use of OTC drugs was reported by $46.1 \%$ of the students in 2012 and $33.6 \%$ in 2017; while 6\% and $4.8 \%$ of students, respectively, declared that they never used these medications. We observed an increasing trend in self-medication with OTC drugs or pharmaceuticals among the students; however, these correlations were not statistically significant.

In the last 6 months prior to the study, the respondents most often used OTC and prescription medications simultaneously (45.2\% in 2012 and $52.7 \%$ in 2017). A total of $13.8 \%$ of the respondents in 2012 and $10 \%$ in 2017 used only prescription drugs, while $26.3 \%$ and $26.8 \%$, respectively, self-administered only OTC medications. During this period, $7.8 \%$ and $6.4 \%$ of the respondents in 2012 and 2017, respectively, used no medications, while $6.9 \%$ and $4.8 \%$, respectively, used only natural preparations, such as honey, garlic, or raspberries. An increase in the simultaneous use of OTC and prescription drugs was observed in the analyzed period; however, these relationships were statistically insignificant.

According to $75.9 \%$ of the respondents in 2012 and $75.6 \%$ in 2017, the fact that medications can be purchased without prescription is beneficial. A different opinion was expressed by $6.5 \%$ of the students in 2012 and $6.8 \%$ in 2017; whereas, $18.9 \%$ and $17.3 \%$, respectively, had difficulty making a clear decision $(p=0.046)$.

An increase in the number of respondents convinced of the possible harmful effects of OTC medications was observed in the analyzed period $-34.1 \%$ and $46.8 \%$ in 2012 and 2017, respectively. A different opinion was expressed by $7.4 \%$ of the respondents in 2012 and $37.7 \%$ in $2017(p<0.001)$.

The studied students declared that when using an OTC drug for the first time they consulted a doctor (51.5\% in 2012 and $44.1 \%$ in 2017), a nurse $(66.4 \%$ in 2012 and $19.5 \%$ in 2017 , $p<0.001)$, a pharmacist $(27.6 \%$ in 2012 and $67.7 \%$ in 2017, $p<0.001)$, or a family member $(30.4 \%$ in 2012 and $68.8 \%$ in 2017, $p<0.001$ ). 
The main reasons for OTC drug use included headache (89.4\% in 2012 and $92.7 \%$ in 2017) and sore throat (88\% in 2012 and $82.7 \%$ in 2017).

Students used OTC drugs until the symptoms subsided (43.8\% in 2012 and 61.4\% in 2017), in accordance with the leaflet (47\% in 2012 and $33.6 \%$ in 2017), until they used the entire package (3.7\% in 2012 and $2.3 \%$ in 2017), or until health deterioration despite treatment (5.5\% in 2012 and $2.7 \%$ in 2017). We observed a rise in OTC drug use until symptoms subsided in the analyzed period; however, these relationships were statistically insignificant.

Reading the leaflet before OTC drug use was confirmed by $35.5 \%$ of the students in 2012 and $39.1 \%$ in 2017 . A total of $31.8 \%$ of the respondents in 2012 and $48.6 \%$ in $2017(p=0.024)$ read the leaflet only if they did not know the drug. About $27.2 \%$ of the students in 2012 and $8.2 \%$ in 2017 never read the leaflet $(p<0.001)$; whereas, $5.5 \%$ and $4.1 \%$ of students, respectively, had difficulty answering the question.

In the last 6 months before the study, the students most often used analgesics (82.5\% in 2012 and $72.3 \%$ in 2017), common cold medications ( $77 \%$ in 2012 and $80 \%$ in 2017), and vitamins (60.4\% in 2012 and $69.1 \%$ in 2017). Results are presented in Table 3.

Table 3. Drugs used for self-medication in the last 6 months
prior to the study

* question with possibility of selecting multiple responses; NS - non-significant.

In the absence of improvement after several days of treatment, $83.4 \%$ of the students in 2012 and $76.4 \%$ in 2017 visited their doctor for advice; whereas $3.2 \%$ and $27.7 \%$ of the students, respectively, changed their medications without prior consultation $(p<0.001)$.

The self-treatment methods used by the students varied considerably. The use of analgesics $(87.1 \%)$ and cough syrups (53.9\%) dominated in 2012, while vitamin therapy (83.2\%), the use of analgesics $(71.4 \%)$, and sedatives $(61.4 \%)$ were most common in 2017. The results are shown in Table 4.

In general, students used between 1 and 15 OTC medications in the last 6 months prior to the study. They usually self- administered 4 (12.9\%) or 5 medications in 2012, and 4 (19.7\%) or $6(13.7 \%)$ medications in 2017 . The results are presented in Table 5.

\begin{tabular}{|l|l|l|l|}
\hline \multicolumn{4}{|l}{ Table 4. Self-treatment methods used by students } \\
\hline Methods* & 2012 & 2017 & $p$ \\
\hline Using pills & $\mathbf{8 7 . 1 \%}$ & $\mathbf{9 1 . 4 \%}$ & NS \\
\hline Using syrups & $\mathbf{5 3 . 9 \%}$ & $59.1 \%$ & NS \\
\hline Using herbs & $45.6 \%$ & $58.2 \%$ & NS \\
\hline Inhalations & $41.5 \%$ & $31.4 \%$ & NS \\
\hline $\begin{array}{l}\text { Rubbing spirit alcohol or } \\
\text { camphor oil into the skin }\end{array}$ & $35.5 \%$ & $9.5 \%$ & $<0.001$ \\
\hline Rest & $33.2 \%$ & $19.1 \%$ & NS \\
\hline Mouth/throat rinsing & $28.1 \%$ & $17.3 \%$ & NS \\
\hline Exercise & $26.3 \%$ & $51.4 \%$ & 0.005 \\
\hline Warming baths & $26.3 \%$ & $10 \%$ & $<0.001$ \\
\hline Vitamin therapy & $24 \%$ & $83.2 \%$ & $<0.001$ \\
\hline Cupping therapy & $22.1 \%$ & $8.6 \%$ & $<0.001$ \\
\hline Sitz baths & $13.4 \%$ & $0.9 \%$ & $<0.001$ \\
\hline Cool compress & $2.3 \%$ & $5.5 \%$ & NS \\
\hline Diet & $1.3 \%$ & $38.6 \%$ & $<0.001$ \\
\hline Analgesic ointments & $0.5 \%$ & $2.3 \%$ & NS \\
\hline
\end{tabular}

* question with possibility of selecting multiple responses; NS - non-significant.

Table 5. Number of drugs used for self-medication in the last 6 months prior to the study

\begin{tabular}{|l|l|l|l|}
\hline \multirow{2}{*}{$\begin{array}{l}\text { Number } \\
\text { of drugs }\end{array}$} & \multicolumn{2}{|l|}{ Percentage of indications } & \multirow{2}{*}{$p$} \\
\cline { 2 - 3 } & 2012 & 2017 & \\
\hline 1 & $2.1 \%$ & $1.1 \%$ & NS \\
\hline 2 & $11.9 \%$ & $10.5 \%$ & NS \\
\hline 3 & $10.6 \%$ & $6.6 \%$ & NS \\
\hline 4 & $12.9 \%$ & $19.7 \%$ & NS \\
\hline 5 & $12.1 \%$ & $11.1 \%$ & NS \\
\hline 6 & $11.7 \%$ & $13.7 \%$ & NS \\
\hline 7 & $8.1 \%$ & $11.1 \%$ & NS \\
\hline 8 & $4.6 \%$ & $8.3 \%$ & NS \\
\hline 9 & $6.1 \%$ & $6.1 \%$ & NS \\
\hline 10 & $3.2 \%$ & $0.8 \%$ & NS \\
\hline 11 & $3.2 \%$ & $4.2 \%$ & NS \\
\hline 12 & $3.2 \%$ & $1.3 \%$ & NS \\
\hline 13 & $3.2 \%$ & $4.2 \%$ & NS \\
\hline 15 & $7.1 \%$ & $1.3 \%$ & NS \\
\hline Total & $100 \%$ & $100 \%$ & \\
\hline
\end{tabular}

NS - non-significant.

A total of $15.2 \%$ of the respondents in 2012 and $14.5 \%$ in 2017 would recommend the use of OTC preparations to their friends, with $70 \%$ and $69.1 \%$, respectively, recommending only medications they know; while, $9.2 \%$ of the students in 2012 and $11.4 \%$ in 2017 would not recommend such treatment. A total of $5.6 \%$ of the respondents in 2012 and 5\% in 2017 found it difficult to answer the question. We observed a rise in the number of people who would not recommend the use of OTC drugs to friends in the analyzed period; however, these relationships were statistically insignificant. 
The main sources of information on OTC drugs mentioned by the respondents included pharmacy personnel $(60.8 \%$ in 2012 and $80.5 \%$ in 2017) and own experience (54.8\% in 2012 and $75.5 \%$ in 2017). Results are shown in Figure 1.

Students relied on their own experiences $(63.1 \%$ in 2012 and $84.1 \%$ in 2017), the opinion of a pharmacist (45.6\% in 2012 and $26.8 \%$ in 2017 ), the opinion of their friends (26.7\% in 2012 and $21.4 \%$ in 2017 ), or the opinion of their doctor $(25.3 \%$ in 2012 and $28.2 \%$ in 2017) when purchasing OTC medications. An increasing tendency to buy OTC drugs as a result of advertisements ( $p<0.001-11.1 \%$ in 2012 and $45.9 \%$ in 2017) and the manufacturer ( $p<0.001-1.4 \%$ in 2012 and $20.9 \%$ in 2017) as well as a decreasing tendency to rely on the opinion of a pharmacist ( $p=0.007$ ) were observed in the analyzed period.

\section{Discussion}

A growing tendency to choose OTC drugs not only for mild conditions, but also for chronic diseases, has been observed in recent years. It is estimated that $35 \%$ of the population regularly uses medications prescribed by a doctor (on average five tablets a day), and a statistical Polish user consumes an average of 31 packages of drugs per year [10]. Plichta et al. found that the use of OTC drugs was declared by $24.8 \%$ of all students, with $45 \%$ of the students having OTC medications with them at the time of survey [10]. Wójtowicz-Chomicz et al. [11] showed in their study of 220 students of Physical Education that all students declared the use of OTC medications. Covington [12] cited the results of a study conducted by the National Council of Patient Information and Education, which included 4300 respondents, and showed that OTC drugs were considered effective by $92 \%$ and safe by $83 \%$ of the respondents. As many as $73 \%$ of the respondents declared that they preferred self-treatment using only OTC medications, and 38\% reported that they used more OTC drugs than they did two years before [12]. Wazaify et al. [13] showed that $32.2 \%$ of 1000 respondents purchased OTC drugs. In our study, $47.9 \%$ of the students in 2012 and $61.6 \%$ in 2017 used OTC medications.

In the aforementioned study by Bażydło et al. [14], the majority of respondents practicing self-medication described their health status as good. In a group of 777 medical students, the respondents rated their health, using a 0-10 score, at an average of $8.01 \pm 1.74$, with higher scores among women and those from smaller towns compared with men and residents from larger urban areas. We found that the respondents in our study usually described their health status as good.

Pęgiel-Kamrat and Zarzeczna-Baran [15] showed in their study of a group of second- and third-year nursing students of the Medical University of Gdansk that only $26.2 \%$ of the respondents declared that they always used drugs in accordance with recommendations.

In our study, students in 2012 most often claimed that they sometimes adhered to medical recommendations (52.1\%), while in 2017 stated that they always complied with medical recommendations (53.6\%). They were usually under medical care several times a year (38.2\% in 2012 and $42.3 \%$ in 2017). In the absence of improvement after several days of self-treatment, most of them decided to make a medical appointment (83.4\% in 2012 and $76.4 \%$ in 2017).

Kasperczyk et al. [16] showed that the use of oral medications, mainly in the form of tablets (from $82.1 \%$ in the faculty of information technology, up to $86 \%$ in the faculty of medicine) and syrups (from $17.9 \%$ in the faculty of psychology, up to $28.5 \%$ in the faculty of information technology), was the most common self-treatment method in the student population. Therapeutic exercise $(15.1 \%$ in the faculty of medicine, $17.9 \%$ in the faculty of psychology), baths ( $18.8 \%$ in the faculty of humanities), body rubbing or consumption of mineral waters $(10.7 \%$ in the faculty of information technology) were also popular [16].
We found that the use of tablets $(87.1 \%)$ and syrups (53.9\%) were the most common forms of self-medication in 2012, while tablets (91.4\%) and vitamin therapy (83.2\%) predominated in 2017 in our study.

Rybus-Potępa and Marczewski [17] presented data on selftreatment, the scale of which ranged from $50 \%$ to $95 \%$, depending on the environment (more common in a rural setting), sex (more common among women), age (more common in the elderly) and education (positive correlation). The authors analyzed the potential reasons for self-medication and concluded that this form of therapy was most often used for typical, mild and short-lasting conditions [17]. A study conducted by the Polish Society for Quality Promotion in Healthcare (as cited in [18]) showed that pain $(83.6 \%)$ and the common cold $(80.3 \%)$ were the most common reasons for purchasing OTC drugs among patients. More than $70 \%$ of the patients were convinced that OTC medications were sufficient to alleviate their symptoms (as cited in [18]). Bażydło et al. [14] demonstrated in their study that OTC drugs were used in the youngest age group mostly for pain (including menstrual pain), the common cold, cough, fever, as well as for immune deficiency and depression in some cases. Low severity of symptoms and a belief that medical consultation is not necessary were the most common reasons for the use of OTC drugs [14]. Johnson et al. [2] showed that $25.9 \%$ of all respondents confirmed the use of sleep-promoting substances, including up to $57 \%$ of respondents using OTC medications. Ramakrishnan and Scheid [19] demonstrated that OTC drugs were used by about $25 \%$ of all patients with sleeping disorders, and were used several times a week by $5 \%$ of the respondents.

According to Pączkowska [20], non-steroidal anti-inflammatory drugs are the most common OTC products purchased by people (57\%). Pain-killers and anti-inflammatory drugs (47.3\%) were also the most common OTC medications among first year students of physical education in the study conducted by Borzęcki et al. [21]. Pain-killers and medications for the common cold and influenza (68.33\% of women and $59.09 \%$ of men) were the most common drugs in the study by Szpringer et al. [22].

In our study, diarrhea, rhinitis, and cough medications were most common among the respondents in 2012; while common cold medications, pain-killers, and vitamins predominated in 2017.

Kasperczyk et al. [16] demonstrated that self-treatment was usually continued until the symptoms subsided (from $55.8 \%$ in the medical faculty, up to $78.5 \%$ in the faculty of information technology) and in accordance with the patient information leaflet (from $21.4 \%$ in the faculty of information technology, up to $43 \%$ in the medical faculty). Consumption of the entire drug package was the least common form of use; whereas, compliance with the instructions provided by the manufacturer was the most common method of dosing. In the absence of efficacy, respondents usually discontinued self-medication (from $5.9 \%$ of students in the faculty of psychology, up to $23.5 \%$ in the faculty of humanities), increased the dose (from $6.9 \%$ in the faculty of medicine, up to $14.3 \%$ in the faculty of information technology), or continued treatment with the same dose (from $1.1 \%$ in the faculty of medicine, up to $12.5 \%$ in the faculty of information technology) [16].

Our respondents in 2012 usually used OTC drugs for as long as recommended in the patient information leaflet (47\%), while in 2017 , this was done until the symptoms subsided (61.4\%).

Zarzeczna-Baran et al. [23] demonstrated that advertisements were the main reason for purchasing OTC medicinal products in $50.6 \%$ of all cases. A study by the National Council of Patient Information and Education showed that $37 \%$ of all respondents asked medical professionals for advice regarding the choice of OTC drug, and only $16 \%$ read the leaflet included in the package [12].

Our study showed that when buying OTC products, the respondents relied on their own experience $(63.1 \%)$ or a pharmacist's opinion (45.6\%) in 2012, as well as their own experience (84.1\%) or advertisements (45.9\%) in 2017. 
According to Bażydło et al. [14], 90\% of the respondents read and followed the recommendations included in the leaflet. Borzęcki et al. [21] found that a vast majority of students (93.5\%) using OTC pharmaceuticals read the patient information leaflets and used the recommended doses. Similarly, 78\% of the respondents from the study by Ratajczak et al. [24] and $87 \%$ of the respondents from the study by Roguska et al. [25] read the patient information leaflets included in the packaging.

In our study, we found that $35.5 \%$ of the respondents in 2012 and $48.6 \%$ in 2017 read the patient information leaflet before using a drug.

It should be emphasized that medical students are a particularly important group from the point of view of a country's drug policy - as they will become health opinion leaders who will play the role of health promoters and educators as well as the decision-makers in the field of health policy. Therefore, the fact that the students included in our study declared a simultaneous use of 4,5 , or 6 medications and decided to opt for OTC drugs instead of a medical appointment when experiencing symptoms is concerning.

Our results indicate that the phenomenon of self-healing is popular in society. Easy access to OCT drugs favors this phenomenon. Yet, OTC drugs are intended for short-term use and too long and excessive OCT medications can cause many side effects. Therefore, there is a need to build an effective self-healing policy (conscious self-medication) and health education. Only in this way can the number of risks associated with self-healing be reduced, such as the risk of drug abuse, interaction with other drugs, and delaying the diagnosis of a serious illness. It is also important for patients to consider the principle that they will take an OTC medicine for it, become familiar with the mechanisms of its operation, and as soon as they observe worrying side effects, they will immediately contact a doctor. The self-healing process to bring benefits must be based on responsibility, safety and reliable advice from doctors and pharmacists.

\section{Conclusions}

1. Students in both 2012 and 2017 knew that OTC stands for over-the-counter drugs and considered the fact that medication can be purchased without prescription to be beneficial. Still, they were aware of the potential risks associated with such treatment and would recommend only products they knew.

2. Self-medication was practiced by most students in both years, and the main reason for the above was lack of time for a medical appointment.

3. Over the last 6 months prior to the study, the students most often used prescription and non-prescription drugs simultaneously, this included 4 OTC drugs.

Source of funding: This work was funded from university's funds.

Conflicts of interest: The authors declare no conflicts of interest.

\section{References}

1. Morin CM, LeBlanc M, Daley M, et al. Epidemiology of insomnia: prevalence, self-help treatments, consultations, and determinants of help - seeking behaviors. Sleep Med 2006; 7(2): 123-130.

2. Johnson EO, Roehrs T, Roth, T, et al. Epidemiology of alcohol and medication as aids to sleep in early adulthood. Sleep 1998: 21(2): 178-186.

3. Randall S, Roehrs TA, Roth T. Leki nasenne dostępne bez recepty i bezsenność. Psychiatr Dyp/ 2009; 6(1): $68-76$ (in Polish).

4. Morin AK, Jarvis CL, Lynch AM. Therapeutic options for sleep-maintenance and sleep-onset insomnia. Pharmacotherapy 2007; 27(1): 89-148.

5. Krajewski-Siuda K. Principiis obsta et respice finem, czyli jak budować politykę samoleczenia. Konferencja Naukowa: Samoleczenie a edukacja zdrowotna, polityka zdrowotna i etyka. Kraków [cited 17.09.2018]. Available from URL: http://www3.uj.edu.pl/alma/ alma/115/56.pdf (in Polish).

6. Krzysztoszek J, Matecka M, Matschay A, et al. Zachowania zdrowotne związane z samoleczeniem w okresie starości. Now Lek 2012; 81(4): 412-417 (in Polish).

7. Raport - rynek produktów OTC w Polsce 2017. Analiza rynku i prognozy rozwoju na lata 2017-2022, PMR, 2017 [cited 17.09.2018]. Available from URL: https://www. pmrpublications.com/pdf/Rynek-produktow-OTC-w-Polsce-2017_promo.pdf (in Polish).

8. Behaviour in School-aged Children: a WHO Cross-national Collaborative Study Research Protocol for the 2001/02 Survey. Edinburgh, 2001 [cited 17.09.2018]. Available from URL: https://www.uib.no/sites/w3.uib.no/files/attachments/hbsc_external_study_protocol_2009-10.pdf.

9. Stalmach M, Jodkowska M, Tabak I, et al. Optymizm życiowy 13-latków w Polsce w kontekście samooceny zdrowia oraz wybranych cech rodziny. Dev Period Med 2013; 17(4): 324-333 (in Polish).

10. Plichta D, Doryńska A, Śpiewak R. Wzorce konsumpcji leków oraz występowanie polekowych działań niepożądanych wśród studentów kierunku zdrowie publiczne. Pol Merk Lek 2012; 32(190): 232-237 (in Polish).

11. Wójtowicz-Chomicz K, Czeczuk A, Huk-Wieliczuk E, et al. Rozpowszechnienie stosowania leków OTC wśród studentów. Forum Med Rodz 2015; 9(2): 173-175 (in Polish).

12. Covington TR. Nonprescription medications and self-care. AJPE 2006; 15(70), doi: https://doi.org/10.5688/aj7006137.

13. Wazaify M, Shields E, Hughes CM, et al. Societal perspectives on over - the counter (OTC) medicines. Fam Pract 2005; 22: 170-176.

14. Bażydło M, Żułtak-Bączkowska K, Zaremba-Pechmann L, et al. Analiza stosowania leków OTC bez konsultacji z lekarzem w poszczególnych grupach wiekowych oraz ocena zapotrzebowania na edukację zdrowotną w tym zakresie. Fam Med Prim Care Rev 2010; 12(2): 127-130 (in Polish).

15. Pęgiel-Kamrat JE, Zarzeczna-Baran MA. Zjawisko samoleczenia wśród studentów pielęgniarstwa Akademii Medycznej w Gdańsku. Zdr Publ 2004; 114(2): 234-237 (in Polish).

16. Kasperczyk J, Jośko J, Klimasara J, et al. Zjawisko samoleczenia wśród studentów wybranych kierunków studiów. Probl Hig Epidemiol 2007; 88(2): 206-209 (in Polish).

17. Rybus-Potępa E, Marczewski K. Samoleczenie - stare zagrożenia czy nowy świat pomocy dla pacjenta. Zdr Pub/ 2001; 111(1): 31-36 (in Polish).

18. Krajewski-Siuda K, Kaczmarek K. Raport z realizacji krajowych warsztatów projektu STEPS w Polsce. UJ, Kraków, 2010 : 1-21 [cited 17.09.2018]. Available from URL:, http://www.steps-ph.eu/wp-content/uploads/Poland_reports_Nov_2010_PL.pdf 2017 (in Polish).

19. Ramakrishnan K, Scheid DC. Treatment options for insomnia. Am Fam Physician 2007; 76(4): 517-526.

20. Pączkowska M. Korzystanie z leków i ich dostępność. Raport z badań, Wydział badań i Analiz Socjologicznych CSIOZ. 2008 [cited 17.09.2018]. Available from URL: http://beta.csioz.gov.pl/dostepnosc.htm (in Polish). 
21. Borzęcki A, Wójtowicz-Chomicz K, Sidor K, et al. Analiza rozpowszechnienia stosowania leków z grupy OTC wśród studentów AWF w Białej Podlaskiej. Fam Med Prim Care Rev 2012; 14(2): 126-128 (in Polish).

22. Szpringer $\mathrm{M}$, Olędzka $\mathrm{M}$, Kosecka J, et al. Use of the over-the-counter drugs by adults and an assessment of the impact of advertisements on consumers. Stud Med 2015; 31(1): 42-47.

23. Zarzeczna-Baran M, Bandurska E, Pęgiel-Kamrat J, et al. Wpływ reklamy na zakup leków dostępnych bez recepty. Ann Acad Med Gedan 2013; 43: 77-87 (in Polish).

24. Ratajczak P, Kus K, Pluskota M, et al. Leki OTC a samoleczenie bólu. Pol Prz Nauk Zdr 2015; 3(44): 147-153 (in Polish).

25. Roguska B, Feliksiak M. Komunikat z Badań Centrum Badań Opinii Społecznej. BS/143/2010, Warszawa, 2010 [cited 17.09.2018]. Available from URL: https://www.cbos.pl/SPISKOM.POL/2010/K_143_10.PDF (in Polish).

Tables: 5

Figures: 0

References: 25

Received: 11.09.2018

Reviewed: 16.09 .2018

Accepted: 3.10 .2018

Address for correspondence:

Prof. Wojciech Kułak

Klinika Rehabilitacji Dziecięcej z Ośrodkiem Wczesnej

Pomocy Dzieciom Upośledzonym "Dać Szansę"

ul. Waszyngtona 17

15-274 Białystok

Polska

Tel./fax: +48 85 745-06-01

E-mail: kneur2@wp.pl 